
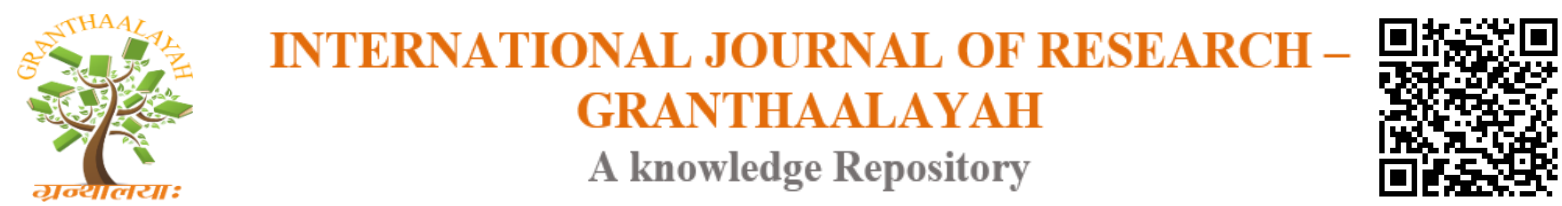

Management

\title{
INFRASTRUCTURE OF ONLINE BANKING IN COMMERCIAL BANKS: CASE OF KERICHO, KENYA
}

\author{
Kiplangat Benard Koros *1 \\ ${ }^{* 1}$ Kenyatta University Box 1354 Kericho, Kenya
}

\begin{abstract}
This research seeks to assess the infrastructure of Online Banking in Commercial Banks: case of Kericho, Kenya. The specific objectives were: To determine the effect of Capacity of IT Infrastructure, to establish the effect of ATM use and to examine the effect of internet access of Online Banking in Commercial Banks in Kenya. Data was collect by Questionnaire, which was adopted from a thesis. Sample size was 154 and target population was 249. Data was analyzed using by descriptive and inferential statistics. Multiple regression analysis method was used in testing relationships among variables. Findings indicate that: there was strong relationship between Capacity of IT Infrastructure and ATM use but a fluctuating, unreliable effect on internet access among the employees in Kericho. ATM use as an infrastructure was the best loaded compared to other two predictors in support of Online Banking. Conclusion: Mobile Network Operation was the least performed. Recommendations: Banks needs to focus on attention at a lower cadre of employees in both private and employees, commercial banks need to carry out training on basic IT knowledge in collaboration with local tea producers, to harness further research of the Capacity of IT Infrastructure.
\end{abstract}

Keywords: Capacity of IT Infrastructure; ATM; Internet Access.

Cite This Article: Kiplangat Benard Koros. (2017). "INFRASTRUCTURE OF ONLINE BANKING IN COMMERCIAL BANKS: CASE OF KERICHO, KENYA." International Journal of Research - Granthaalayah, 5(12), 329-336.

\section{Introduction}

\subsection{Background}

Customers access e-banking services using an intelligent electronic device, such as a personal computer, personal digital assistant, Automated Teller Machine (ATM), Kiosk, or touch Tone telephone Employees can improve workplace safety, decrease expenses and maintain client relationships by use of Online Banking Moreover, Online Banking is one of the important functions of management which plays an important role in providing information that is required for crucial decision making which directly affects the performance of the employees. However, research also show that the World Bank runs the Information for Development Program (info 
Dev), that's Rural ICT Toolkit which analyses the costs and possible profits involved in such a venture and shows that there is more potential in developing areas than many might assume.

According to Liyala, (2012) a number of developing countries such as Peru, Mexico, Pakistan have proven their skills in IT and are using these skills to build on ICT for Development (ICT4D) projects that taps local potential which is a key indigenous partner in the growth of the sector. The balance of trade for these nations due to imports in both hardware and software might be an additional consideration (Mathur, 2006; Munyua, 2000). As Orlikowski and Barley (2001) mention, technologies are simultaneously social and physical artifacts, and have not been realized by a number of scholars, hence, the code phrase "the social construction of technology" which refers to the role of human agency in technological change. From the implementation point of view, designers incorporate into technical systems assumptions about usage by endusers, physical considerations, technical operation skills, management skills, level of IT infrastructure, design traditions, as well as taken-for granted views of the world for which the system is meant to provide solutions.

\section{Capacity of IT Infrastructure}

According to Umble \& Haft, ( 2003), IT infrastructure includes: Cables, Local Area Network (LAN), Wide Area Network (WAN), Network Security (NS), Network components and Network Software's(NSft). Study by Sanja (2017:p100) contend that Radiofrequency Transmitter Receiver (RFTR), System security (SyStu), Application, software, Database (Dbase), Servers and Operating System software (OS). Sanja et al., (2014) further argues that the case of developing countries,online Banking is affected by the ICT infrastructure of the country. Optimum IT infrastructure include: hardware and networking (Verville, Bernadas, \& Halingten, 2005).Moreover, completeness, compatibility, usability and integrality of the current systems should be achieved (Yang, Wu, \& Tsai, 2007) and current infrastructure might be upgraded (Ananda et al., 2003; Palaniswamy \& Frank, 2002).In this study the Capacity of IT Infrastructure on online Banking is moderated by age and gender. Older system operators tend to face more difficulty in processing new or complex system, thus affecting their learning of new technologies (Morris et al., 2005; Plude and Hoyer 1985). Hence, compared to younger system operators, older system operators, tend to place greater importance on the availability of adequate support (Hall and Mansfield, 1975).

In this study to assess the Capacity of IT Infrastructure on online Banking is moderated by age and gender. Moreover, men, more than women, are willing to spend more effort to overcome different constraints and difficulties to pursue their goals, with women tending to focus more on the magnitude of effort involved and the process to achieve their objectives (Henning and Jardim 1977; Rotter and Portugal 1969; Venkatesh and Morris 2000). Thus, men tend to rely less on Capacity of IT Infrastructure when considering use of a new technology whereas women tend to place greater emphasis on external supporting factors. This can also be explained partly by the cognitions related to gender roles in society where men tend to be more task-oriented .The following hypothesis is therefore formulated: $\mathrm{H} 2 a$ : Capacity of IT Infrastructure has significant effect on online Banking in employees $H 2 b$ : Capacity of IT Infrastructure have significant effect on online Banking 


\section{Mobile Money Transfer}

Mobile Money Transfer (MMT) is an innovation to transfer money using the Information and Communications Technology (ICT) infrastructure of the Mobile Network Operators (Mbiti 2011). The MNO infrastructure becomes a channel for funds transfer between customers of one or multiple MNOs to both the cellular terminals or to business organization to pay, procure goods or to a bank account to transact through the account. Where the transfer is from mobile phone to mobile phone, it is termed as peer to peer or person to person $(\mathrm{P} 2 \mathrm{P})$; the transaction from mobile phone to the bank or a business is termed as person to business(P2B) to pay for goods or services or bulk payments e.g., wages (Mbiti et al 2012). These definitions are not intended to be exhaustive but as indicative due to the rapid evolution of MMT.

\section{Methodology, Analysis, Finding, Discussions and Conclusions}

This research used a case study approach of descriptive research design. A case study research is the most common type of design that is best method for collecting original data for the purpose of describing phenomena in population by focusing on certain focused group (Mugenda and Mugenda,2003). The study focused on all lower cadre permanent employees of Mau Tea Multipurpose cooperative society ltd from which the respondents were drawn. It covered two main areas: those working in the factory and those working in the estate. The research relied on the use of questionnaires with most closed ended items designed in a likert scale.

A study research instrument was evaluated since it must be both valid and reliable. Validity is the accuracy and meaningfulness of inferences, which are based on research results (Mugenda, 2003). The validity of the instrument is acceptable if it produces consistent data. (Chava, and Nachmias, 1996).Reliability is a measure of the degree to which a research instrument yields consistent results or data after repeated trials (Mudgenda\&Mugenda, 2003). An instrument is reliable if it measures what is supposed to measure. For this to be achieved, piloting was done in one purposively selected private tea sector; a pre-test (Test-Retest method) was carried out in one of the private tea company, Kaisugu Tea Ltd.

\section{Anti-Image Matrices Correlation}

Results from (Table 4.1) of Anti-image Matrices on iteration, the MSA on Internet access (IA), ATM operation and Capacity of IT Infrastructure variables extracted in the analysis was greater than 0.5 hence supporting the analysis on the Correlation and Measure of Sampling Adequacy (MSA).Results confirm the higher criteria above 0.5 (Mediocre level) supports Employee savings. Since majority of results were above the mediocre level. Value closer to 1 suggests patterns of correlations are relatively compact and so factor analysis should yield distinct and reliable factors Results.

Table 4.1:Anti-image Matrices Correlation

\begin{tabular}{|l|l|l|l|}
\hline & CITI & ATM & IA \\
\hline \multirow{4}{*}{ Anti-image } & $.0 .63^{\mathrm{a}}$ & $.0 .63^{\mathrm{a}}$ & -.355 \\
\cline { 2 - 4 } & -.355 & -.355 & $.818^{\mathrm{a}}$ \\
\cline { 2 - 4 } & -.771 & -.771 & .646 \\
\hline
\end{tabular}




\begin{tabular}{|l|l|l|l|}
\hline Correlation & -.453 & -.453 & .297 \\
\cline { 2 - 4 } & -.536 & -.536 & -.084 \\
\cline { 2 - 4 } & .216 & .216 & .109 \\
\cline { 2 - 4 } & .175 & .175 & -.051 \\
\hline
\end{tabular}

Results confirms the effectiveness and higher criteria above 0.5 (Mediocre level) and moderate validation analysis that indicated that the ATM and CITI have strong support on the applicability on Employee savings, since their results were more than 0.7.though MNO and IA posted lower values closer to the cut off threshold, hence strongly threatening Employee savings. Similar studies done by Yi el at., (2012) argue that the inclusion of some unnecessary predictors as a tool on Employee savings, end up changing the meaning or replicate the findings. Similar studies have also found ATM to be non-significant in predicting employee savings (See Cheng, Liu and Qian 2010; Wu, Tao and Yang 2010).

Study done by Al-Eqab and Ismail (2011) found that ATM operations were significant hence demonstrated that extended, timely, frequent, aggregated and savings should be particularly useful for employees to enable them to respond quickly to changing environmental and market demands. Based on this information, officers prefer to request the use of more Mobile Network Operations, ATM operations practices during employee savings. In this sense, Galani et al. (2010) showed that the more the information that results from CITI were significant and of greater quality, the more it provides support for leaders to establish strategic and operational on employee savings.

In the banking sector empirical studies was carried using DeLone and McLean model (Aburas, 2013 and Mashhour, 2008). Most of the studies were on electronic banking (Okechi, 2013; Olatokun, 2012; Andoh-Baidoo, 2010). Okechi (2013) in his study showed that ATM was the most heavily used and customers were not satisfied by the service quality of ATM, Internet access (IA) and IT knowledge should encourage their customers to use e banking. Similar study done by Aburas (2013) found that level of information services provided to the customers was an important and critical factor to affect perceived quality. Results of study by Koo (2013) indicated that trust in Capacity of IT Infrastructure (CITI) and ATM operation was associated with customer satisfaction. In a study on satisfaction with web based decision support systems, Bharati et al., (2004) found that main factors to impact decision making satisfaction were information quality and system quality.

Similar Study done by Anu and Mukherjee (2014), carried out research and established that there is no significant relationship between IA and ATM operation $\mathrm{r}=.030, \mathrm{p}=0.601$ ) and it supports $\mathrm{H} 1$ and H2. So this study contend that ATM influence employee sayings. Further results from the table given above it is seen that there exists a significant direct association between system quality and user satisfaction $(\mathrm{r}=0.363, \mathrm{p}=0.000)$ of decision support system in the banking sector. This result support $\mathrm{H} 1 \mathrm{~b}$ and this study can say that IA positively influence user satisfaction with decision support employee savings in the banking sector. Similar research by Sanja et al., (2014) on mobile money (Mpesa in Kenya) indicated that there is no significant relationship between Mobile Network Operations (-.101). $(\mathrm{r}=0.086, \mathrm{p}=0.132)$ and hypothesis was not supported. Further results of Pearson correlation from the study show that there is a negative relationship between Mobile Network Operations and employee savings. 


\section{Testing of Hypotheses of the Research}

The hypothesis was tested and it yielded results as shown on (Table 4.4). Results indicated that Management skills have significant (.004), since $\mathrm{P}<0.05$ which was evident that Management's skill has influence on the use of IFMIS as a mediator i.e $M g t S$ ( $\operatorname{sig} 0.04$ but weak significant) $\beta=0.636$, hence the study rejected the null hypothesis, though a weak significant. This study also tested for multi collinearity statistics tolerance by means of Variance Inflation Factor, the results indicated that the Variance Inflation Factor (VIF) is not greater than 2, hence not problematic.

H1: ATM use has no significant influence on Employee savings among the lower cadre employees in Mau Tea Multipurpose Cooperative Society Ltd

H2: Capacity of IT Infrastrucure has no significant influence on Employee savings among the lower cadre employees in Mau Tea Multipurpose Cooperative Society Ltd.

H3: Internet access has no significant influence on Employee savings among the lower cadre employees in Mau Tea Multipurpose Cooperative Society Ltd.

To analyse the hypothesis the study Used a technique of multiple regression analysis, where by the constructs of mobile banking, : ATM and IT knowledge and savings was used to determine the actual prediction equation and show the direction, collinearity and strength of the relationship among the variables. The assumed linear model was of the form:

$Y=b_{0}+b_{1} X_{1}+b_{2} X_{2}+b_{3} X_{3}++e$

Where:

$\mathrm{Y}=$ Savings

$\boldsymbol{X}_{\mathbf{1}}=$ Mobile Network Operations

$\boldsymbol{X}_{2}=$ ATM use

$X_{3}=$ CITI

$\mathrm{X} 4=$ Internet access

$b_{0}$ is the constant implying the level of Savings that does not depend on the three variables investigated and $b_{1}, b_{2}$ and $b_{3}$ are constants of proportionalities for mobile banking, ATM and IT Knowledge respectively.

\section{Results for Test of Hypothesis}

Results ATM $=(.276)$, CITI $=(.140), \mathrm{IA}=(.419)$. The model was tested with regression analysis and findings were extracted, the regression model equation below was extracted. Results from Summary of Hypothesis Test

$y=\alpha+\beta_{1} X_{1}+\beta_{2} X_{2}+\beta_{3} X_{3}+e$

$\mathrm{X}_{1}=$ Mobile Network Operations (MNO), $\mathrm{X}_{2=}$ ATM use (ATM), X3 = IT knowledge (ITK) and $\mathrm{X}_{4}=$ Internet access (IA)

Note $\alpha=\beta_{0=\text { constant }}$

Where: 
$\mathrm{Y}^{\prime}=$ A predicted value of $\mathrm{Y}$ (which is dependant variable).

$\alpha=$ the value of $Y$ when $X$ is equal to zero. This is also called the "Y Intercept".

$\beta=$ the change in $Y$ for each 1 increment change in $X .(X 1 X 2)=$ an $X$ score on independent variable for which the study is trying to predict a value of $Y$.

$\mathrm{X}=$ independent variable $(\mathrm{X}, \mathrm{X} 2, \mathrm{X} 3, \mathrm{X} 4)$ )

$\mathrm{e}=$ Residual or error terms (represent by e)

$\mathrm{y}=\alpha+\beta_{1}(\mathrm{MNO})+\beta_{2}(\mathrm{ATM})+\beta_{3}(\mathrm{ITK})+\beta_{4}(\mathrm{IA})+\mathrm{e}$

$\mathrm{Y}=$ Employee savings, $\alpha=(4.885), \mathrm{MNO}=(.166), \mathrm{ATM}=(.276), \mathrm{CITI}=(.140)$,

$\mathrm{IA}=(.419) \quad$ Replacing the path coefficients in equations:

$\mathrm{y}=4.885-.166(\mathrm{MNO})+.276(\mathrm{ATM})+0.140(\mathrm{ITK})+.419(\mathrm{IA})+\mathrm{e}$

Table 4.2: Regression Coefficients

\begin{tabular}{|l|l|l|l|}
\hline \multirow{2}{*}{ Model } & $\begin{array}{l}\text { Un standardized } \\
\text { Coefficients }\end{array}$ & $\begin{array}{l}\text { Standardized } \\
\text { Coefficients }\end{array}$ & $\mathbf{p}$ \\
\cline { 2 - 4 } & B & Beta & \multicolumn{1}{c|}{ Sig } \\
\hline (Constant) & 4.885 & & .000 \\
\hline CITI & -.166 & -.422 & .001 \\
\hline ATM use(ATM) & .276 & .321 & .000 \\
\hline Internet access(IA) & .419 & .458 & .003 \\
\hline
\end{tabular}

Results from (Table 4.2) on regression model, shows that when all independent variables are kept constant on Employee savings, $b=4.885$. The interaction of variables indicate that a unit increase in CITI caused a decrease (negative) on Employee savings among the lower cadre employees in Mau Tea Multipurpose Cooperative Society Ltd by a factor of - .166 ; a unit increase in ATM use variable would cause an increase on Employee savings among the lower cadre employees in Mau Tea Multipurpose Cooperative Society Ltd a factor of .276; and a unit increase in IA would cause an increase on Employee savings among the lower cadre employees in Mau Tea Multipurpose Cooperative Society Ltd by a factor of 419._Coefficients (representing the relationships between variables) were estimated by standardizing the regression weights coefficients (Yuen 2007). Residual or error terms (represent by e) are exogenous independent variables that are not directly measured and reflect unspecified causes of variability in the outcome or unexplained variance plus any error due to measurement (Lleras 2005). This study established that there was strong relationship between IT knowledge and Internet access on the Employee savings among the lower cadre employees in Mau Tea Multipurpose Cooperative Society Ltd by (.601) and it also established that there was a weak effect between Employee savings and Mobile Network Operations and ATM use on Employee savings among the lower cadre employees in Mau Tea Multipurpose Cooperative Society Ltd

Employee savings and Mobile Network Operations was the least performed as a predictor: (fl $0.579, \alpha 0.690$ and ai 0.63 ) while Capacity of IT Infrastructure (CITI ) as a predictor was the best since it loaded highly hence the variable had the best weight as predictor compared to other predictors : (fl $0.978, \alpha 0.901$ and ai 0.86 as indicated in chapter 4 . In yet another study to investigate the role played by motivation in e-learning technology adoption with ATM, Maldonado, Khan, Moon and Rho (2009) found CITI to be significant in predicting financial savings. Cheng et al., (2008) also examined the acceptance of internet banking and found that CITI predict customer's intention to use internet banking. 


\section{Conclusion}

The sample of partial correlation for Mobile Network Operation was generally the least performed. This study is similar with that done by Wang et al., 2012), which established that the Internet access provider is an important factor in the establishment and maintenance on Financial Employee savings. The employee saving support comes mainly from the Internet access and Mobile Network Operation which are reliable services to ATM operations (Zhang et al., 2015).

Results confirms the effectiveness and higher criteria above 0.5 (Mediocre level) and moderate validation analysis that indicated that the ATM and CITI have strong support on the applicability of Employee savings. MNO and IA posted lower values closer to the cut off threshold, hence strongly threatening Employee savings. Similar studies done by Yi el at., (2012) argue that the inclusion of some unnecessary predictors as a tool on Employee savings, end up changing the meaning or replicate the findings. Similar studies have also found ATM to be nonsignificant in predicting employee savings (See Cheng, Liu and Qian 2010 ; Wu, Tao and Yang 2010).

\section{Recommendations}

Banks needs to focus on attention at a lower cadre of employees in both private and employees who are critical mass and who are involved in daily financial transactions. There is need for commercial banks to carry out for research on Capacity of IT Infrastructure, which should involve the training on basic bank stockholders in collaboration with local tea producers in order to harness the ready market of the would be clients.

\section{Reference}

[1] Aburas, R., Raihan, N., \& Hamid, A. (2013).Measurement models of automated systems Quality: A Study on the Banking Sector. International Journal of Scientific \& Technology Research, 2(5), 74-79.

[2] Bharati, P., (2004).Employees and Information Systems: Task Support Satisfaction from the Other Side. Journal of Computer Information Systems, 43(2): 93 - 102.

[3] Bharati, P., \& Chaudhury, A., (2012). Product Customization on the Web: An Empirical Study of Factors Impacting Choice board User Satisfaction. Information Resources Management Journal, 19 (2): $69-81$.

[4] Cheng,D., Liu,G., Song, Y-F and Qian, C ., (2008) Adoption of Internet Banking: An Integrated Model". Proceeds of the 4th International Conference on Wireless Communications, Networking and Mobile Computing, 12-14 Oct. 2008, Dalian.

[5] Koo, C., Wati, Y., \& Chung, N., (2013). A Study of Mobile and Internet Banking Service: for IS Success Model. Asia Pacific Journal of Information Systems, 23(1), 65-86.

[6] Lindley, P., \& Walker, S., N., (1993). Theoretical and methodological differentiation of Moderation and mediation. Nursing research, 42, 276-279

[7] Mead, D., (1994). The Contribution of Small Enterprises to Employment Growth in Southern and Eastern Africa. World Development, 22(12), 1881-1894.

[8] Mead, D., (1999). MSEs tackle both poverty and growth (but in differing proportions). In K. King \& S. McGrath (Ed.), Enterprise in Africa: between poverty and Growth. London: Intermediate Technology Development Group Publishing. 
[9] Mead, D., \&Liedholm, C., (1998). The Dynamics of Micro and Small Enterprises in Developing Countries. World Development, 26(1), 61-74.

[10] Maldonado,U., P., T., Khan,G., F., Moon, J., and Rho, J., J., (2009). - Banking motivation, Savings Acceptance/ Educational Portal in Developing Countries". Proceeds of the 4th International Conference on Computer Sciences and Convergence Information Technology

[11] Morris, S., A., Marshall, T., E., \& Rainer, R., K., (2012). Impact of User Satisfaction and Trust on Virtual Team Members. Information Resources Management Journal, 15 (2): 23 - 69.

[12] Orlikowski, W., J., (2013). Using Technology and Constituting Structures: A Practice Lens for Study using Technology in Organizations. Organization Science, 11(4), 404-428.

[13] Sanja, Michael, Mutongwa , (2017).PhD Thesis, Department of Computer Science and software engineering, School of Informatics and Innovation Systems, Jaramogi Oginga Odinga University of Science and Technology Page;120-140;168 -170

[14] Sanja Michael Mutong'Wa, Wasilwa, K., Mneria E., Mengich (2014).A Comparative Study Of Critical Success Factors (Csfs) In Implementation Of Mobile Money Transfer Services In Kenya.

[15] European Journal of Engineering and Technology Vol. 2 No. 2, 2014 ISSN 2056-5860Saxenian, A., (1994). Regional advantage: Culture and competition in Silicon Valley and Route 128. Cambridge: Harvard University Press.

[16] Serida, J., Morales, O., \& Nakamatsu, K. (2012). Global Entrepreneurship Monitor Peru 2011 (pp. 146). Lima: Universidad ESAN. Sessional paper no. 2 of 2005 on development of micro and small enterprises for Wealth employment creation for poverty reduction, Government printers, Nairobi.

[17] Wambari, T (2009) Mobile banking in developing countries. A case study on Kenya Weil, David N., Isaac Mbiti, and Francis Mwega (2014) Mobile Banking: The Impact of M-Pesa in Kenya; Brown University and NBER.

[18] Víctor Pérez Centeno, (2014). Entrepreneurial Networking of Small Businesses in Latin-America the Case of Villa el Salvador in Peru. Villarán, F. (2010). Politicas e Instituciones de Apoyo a la Micro y Pequeña Empresa en el Peru.

[19] In C. Ferraro \& G. Stumpo (Eds.), Políticas de Apoyo alas Pymes en América Latina: Entre Advances Innovadores Desafios Institucionales (pp. 343-384

[20] Yuen, Desmond. 2007. Antecedents of Budgetary participation: Enhancing employees ${ }^{\text {ee }}$ Job Performance. Managerial Auditing Journal. , Vol.22 No.5. Pp.533-548

*Corresponding author.

E-mail address: Korosbenerd @gmail.com 